\title{
Mitteilungen der SGG
}

Gefässchirurgie 2013 · 18:606-606

DOI 10.1007/s00772-013-1136-6

C Springer-Verlag Berlin Heidelberg 2013

Korrespondenzanschrift für die Mitteilungen

der SGG:

Prof. Dr. Lorenz Gürke

Gefässchirurgie und Nierentransplantation

Universitätsspital

4031 Basel, Schweiz

Tel.: +416126572 22

Fax: +41622658851

Lorenz.Guerke@usb.ch

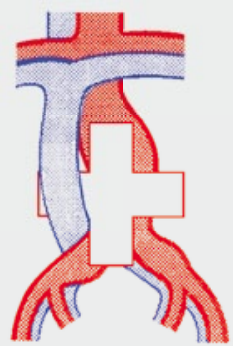

Die Inhalte der Mitteilungsseiten der Zeitschrift „Gefässchirurgie“ liegen in der Verantwortung der entsprechenden

Fachgesellschaften. Herausgeber und Verlag übernehmen keine Verantwortung für diese Rubrik.

\section{Preisverleihung}

Anlässlich der Jahrestagung der Schweizerischen Gesellschaft für Chirurgie im Juni 2013 in Bern wurden von Seiten der Schweizerischen Gesellschaft für Gefäßchirurgie die folgenden Preise verliehen:

\section{Beste wissenschaftliche Arbeit (1500 CHF)}

An C. Dubuis, A. Longchamp, F. Alonso, F. Saucy, J. Haefliger, J.-M. Corpataux, S. Déglise (Lausanne).

An external mesh reinforcement of the human saphenous vein reduces inadequate remodeling and the development of intimal hyperplasia in an ex-vivo model of arterialization.

\section{Bestes SGG Poster (500 CHF)}

An C. Geppert, R. Marti, L. Gürke, P. Stierli (Aarau, Basel). Malignant venous tumours - a case of a leiomyosarcoma of the great saphenous vein and a case of an epithelioid haemangioendothelioma of the femoral vein. 